\title{
Supervision Towards Improving Online Learning As Soon As Possible During The Covid-19 Pandemic
}

\section{Supervisi Menuju Perbaikan Pembelajaran Daring Secepatnya Semasa Pandemi Covid 19 Di SMKN 11 MaLANG}

\author{
Gunawan Dwiyono(1) Djoko Kustono(2) \\ 1), 2) Porgram Studi Magister Pendidikan Kejuruan, Universitas Negeri Malang \\ Jl. Semarang No. 5 Malang Kode Post 65145 \\ e-mail: dwiyono1967@gmail.com
}

\begin{abstract}
The big role of school principals in supporting the improvement of the quality of education should be reviewed comprehensively and completely based on problems in the school. That since March 16, 2020 the government has called for learning to be carried out online. So, the change so quickly in the way of learning is surprising for both teachers and students, various problems arise. So that the school also began to anticipate participating in finding solutions to anticipate problems that occur in online learning. There are 3 direct policies simultaneously that we must implement in a situation of learning crisis at that time, namely social restrictions due to the COVID-19 pandemic forcing online learning, independent learning without the UN so that students can assess student competencies in the form of written tests or other more comprehensive forms of assessment, such as portfolios and assignments (group assignments, written papers, etc.), curriculum in special conditions or emergency curriculum, schools can use a curriculum that suits the learning needs of students. This situation is discussed in this paper, the efforts of Public Vocational High School 11 Malang to supervise to improve online learning that was previously completely unprepared. Suddenly, all teachers should do online learning using IT media, repairs can be made quickly and effectively during the pandemic.

Keywords: Online learning, supervision, educational quality
\end{abstract}

\begin{abstract}
ABSTRAK
Peran besar kepala sekolah dalam mendukung peningkatan kualitas pendidikan sebaiknya ditinjau secara komprehensif dan utuh berdasar problematika di sekolahnya. Bahwa sejak 16 Maret 2020 pemerintah menghimbau pembelajaran dilaksanakan secara daring. Maka perubahan begitu cepat cara pembelajaran ini mengejutkan bagi guru dan siswa, berbagai persoalan muncul. Sehingga pihak sekolah juga mulai turut mengantisipasi ikut mencari solusi untuk mengantisipasi permasalahan yang terjadi di pembelajaran daring. Ada 3 kebijakan langsung serentak yang harus kita terapkan dalam situasi krisis pembelajaran saat itu yaitu pembatasan sosial akibat pandemi covid 19 memaksa pembelajaran daring, merdeka belajar tanpa UN sehingga bisa menilai kompetensi siswa dalam bentuk tes tertulis atau bentuk penilaian lainnya yang lebih komprehensif, seperti portofolio dan penugasan (tugas kelompok, karya tulis, dan sebagainya), kurikulum dalam kondisi khusus atau kurikulum darurat, sekolah dapat menggunakan kurikulum yang sesuai dengan kebutuhan pembelajaran peserta didik. Situasi inilah yang dibahas pada tulisan ini upaya SMK Negeri 11 Malang melakukan supervisi untuk memperbaiki pembelajaran daring yang sebelumnya sama sekali tanpa persiapan. Tiba tiba pada semua guru harus melakukan pembelajaran daring menggunakan media IT, bisa dilakukan perbaikan secara cepat dan efektif semasa pandemi.

Kata kunci: Pembelajaran daring, supervisi, kualitas pendidikan
\end{abstract}

\section{PENDAHULUAN}

Pengertian istilah supervisi Suharsimi Arikunto (2004:4) mengemukakan, "Supervisi yang berasal dari bahasa Inggris terdiri dari dua akar kata, yaitu super yang artinya "diatas" dan vision yang mempunyai arti "dilihat", maka secara keseluruhan supervisi diartikan sebagai "melihat dari atas", dengan pengertian itulah maka supervisi diartikan sebagai kegiatan yang dilakukan oleh pengawas dan kepala sekolah sebagai pejabat yang berkedudukan di atas atau lebih tinggi dari guru untuk rnelihat atau mengawasi pekerjaan guru". Adam dan Dickey (Sahertian, 2000: 17) berpendapat bahwa "supervisi adalah program yang berencana untuk memperbaiki pengajaran. Program itu pada hakikatnya adalah perbaikan hal belajar dan mengajar".

Edaran Menteri Kesehatan Nomor HK.02.01/MENKES/335/2020 tentang Protokol Pencegahan Penularan Corona Virus Disease (Covid-19) di Tempat Kerja Sektor Jasa dan Perdagangan (Area Publik) dalam Mendukung Keberlangsungan Usaha. Ada beberapa klausul yang harus dipatuhi antara lain: 
Perusahaan diwajibkan membatasi jarak pekerjanya, termasuk meja kerja dan tempat duduk minimal 1 meter. Pengaturan jumlah pekerja yang masuk agar memudahkan penerapan menjaga jarak. Lokasi tempat kerja juga harus bersih dan higienis dengan melakukan pembersihan berkala dengan pembersih dan disinfektan yang sesuai selama 4 jam sekali, terutama pegangan pintu dan tangga, tombol lift, peralatan bersama, area dan fasilitas umum. Aturan inilah yang menyebabkan sekolah pembelajaran luring tidak memungkinkan sehingga dihimbau melaksanakannya pembelajaran secara daring.

Di semua jenjang sekolah baik TK, PAUD, SD, SMP, SMK SMK dan Perguruan tinggi semua serentak melaksanakan pembelajaran daring. Pembelajaran daring adalah pembelajaran yang mampu mempertemukan mahasiswa dan dosen untuk melaksanakan interaksi pembelajaran dengan bantuan internet (Kuntarto, 2017).Pada tataran pelaksanaanya pembelajaran daring memerlukan dukungan perangkat-perangkat mobile seperti smarphone atau telepon adroid, laptop, komputer, tablet, dan iphone yang dapat dipergunakan untuk mengakses informasi kapan saja dan dimana saja (Gikas \& Grant, 2013). Perguruan tinggi pada masa WFH perlu melaksanakan penguatan pembelajaran secara daring (Darmalaksana, 2020). Pembelajaran secara daring telah menjadi tuntutan dunia pendidikan sejak beberapa tahun terakhir (He, Xu, \& Kruck, 2014).Pembelajaran daring dibutuhkan dalam pembelajaran di era revolusi industri 4.0 (Pangondian, Santosa, \& Nugroho, 2019).

Merdeka Belajar pada SE No. 1 Th 2020 yang ditandatangani Selasa (18/2) oleh Sekretaris Jenderal (Sekjen) Kemendikbud, Ainun Naim tentang Kebijakan Merdeka Belajar dalam Penentuan Kelulusan Peserta Didik dan Penerimaan Peserta Didik Baru Tahun Ajaran 2020/2021 ditujukan kepada Gubernur dan Bupati/Wali Kota seluruh Indonesia. SE tersebut menyampaikan agar Gubernur dan Bupati/Wali Kota seluruh Indonesia melakukan persiapan dengan berdasarkan sebagai berikut: Empat Pokok Kebijakan Pendidikan "Merdeka Belajar", di Jakarta, Rabu (11/12).

Arah kebijakan baru penyelenggaraan USBN, kata Mendikbud, pada tahun 2020 akan diterapkan dengan ujian yang diselenggarakan hanya oleh sekolah. Ujian tersebut dilakukan untuk menilai kompetensi siswa yang dapat dilakukan dalam bentuk tes tertulis atau bentuk penilaian lainnya yang lebih komprehensif, seperti portofolio dan penugasan (tugas kelompok, karya tulis, dan sebagainya). "Dengan itu, guru dan sekolah lebih merdeka dalam penilaian hasil belajar siswa. Anggaran USBN sendiri dapat dialihkan untuk mengembangkan kapasitas guru dan sekolah, guna meningkatkan kualitas pembelajaran," terang Mendikbud.
Selanjutnya, mengenai ujian UN, tahun 2020 merupakan pelaksanaan UN untuk terakhir kalinya. "Penyelenggaraan UN tahun 2021, akan diubah menjadi Asesmen Kompetensi Minimum dan Survei Karakter, yang terdiri dari kemampuan bernalar menggunakan bahasa (literasi), kemampuan bernalar menggunakan matematika (numerasi), dan penguatan pendidikan karakter," jelas Mendikbud.

Pelaksanaan ujian tersebut akan dilakukan oleh siswa yang berada di tengah jenjang sekolah (misalnya kelas 4, 8, 11), sehingga dapat mendorong guru dan sekolah untuk memperbaiki mutu pembelajaran. Hasil ujian ini tidak digunakan untuk basis seleksi siswa ke jenjang selanjutnya. "Arah kebijakan ini juga mengacu pada praktik baik pada level internasional seperti PISA dan TIMSS," tutur Mendikbud.

Sedangkan untuk penyusunan Rencana Pelaksanaan Pembelajaran (RPP), Kemendikbud akan menyederhanakannya dengan memangkas beberapa komponen. Dalam kebijakan baru tersebut, guru secara bebas dapat memilih, membuat, menggunakan, dan mengembangkan format RPP. Tiga komponen inti RPP terdiri dari tujuan pembelajaran, kegiatan pembelajaran, dan asesmen. "Penulisan RPP dilakukan dengan efisien dan efektif sehingga guru memiliki lebih banyak waktu untuk mempersiapkan dan mengevaluasi proses pembelajaran itu sendiri. Satu halaman saja cukup," jelas Mendikbud.

Dalam penerimaan peserta didik baru (PPDB), Kemendikbud tetap menggunakan sistem zonasi dengan kebijakan yang lebih fleksibel untuk mengakomodasi ketimpangan akses dan kualitas di berbagai daerah. Komposisi PPDB jalur zonasi dapat menerima siswa minimal 50 persen, jalur afirmasi minimal 15 persen, dan jalur perpindahan maksimal 5 persen. Sedangkan untuk jalur prestasi atau sisa 0-30 persen lainnya disesuaikan dengan kondisi daerah. "Daerah berwenang menentukan proporsi final dan menetapkan wilayah zonasi," ujar Mendikbud.

Mendikbud berharap pemerintah daerah dan pusat dapat bergerak bersama dalam memeratakan akses dan kualitas pendidikan "Pemerataan akses dan kualitas pendidikan perlu diiringi dengan inisiatif lainnya oleh pemerintah daerah, seperti redistribusi guru ke sekolah yang kekurangan guru," pesan Mendikbud.

Kurikulum Kondisi Khusus merupakan kebijakan Kementerian Pendidikan dan Kebudayaan (Kemendikbud) dengan menerbitkan Keputusan Menteri Pendidikan dan Kebudayaan Republik Indonesia Nomor 719/P/2020 tentang Pedoman Pelaksanaan Kurikulum pada Satuan Pendidikan dalam Kondisi Khusus. Satuan pendidikan dalam kondisi khusus dapat menggunakan kurikulum yang sesuai dengan kebutuhan pembelajaran peserta didik.

Pelaksanaan kurikulum pada kondisi khusus bertujuan untuk memberikan fleksibilitas bagi satuan 
pendidikan untuk menentukan kurikulum yang sesuai dengan kebutuhan pembelajaran peserta didik. Satuan pendidikan pada kondisi khusus dalam pelaksanaan pembelajaran dapat 1) tetap mengacu pada Kurikulum Nasional; 2) menggunakan kurikulum darurat; atau 3) melakukan penyederhanaan kurikulum secara mandiri. "Semua jenjang pendidikan pada kondisi khusus dapat memilih dari tiga opsi kurikulum tersebut," terang Mendikbud.

Kurikulum darurat (dalam kondisi khusus) yang disiapkan oleh Kemendikbud merupakan penyederhanaan dari kurikulum nasional. Pada kurikulum tersebut dilakukan pengurangan kompetensi dasar untuk setiap mata pelajaran sehingga guru dan siswa dapat berfokus pada kompetensi esensial dan kompetensi prasyarat untuk kelanjutan pembelajaran di tingkat selanjutnya.

Kemendikbud juga menyediakan modul-modul pembelajaran untuk Pendidikan Anak Usia Dini (PAUD) dan Sekolah Dasar (SD) yang diharapkan dapat membantu proses belajar dari rumah dengan mencakup uraian pembelajaran berbasis aktivitas untuk guru, orang tua, dan peserta didik. "Dari opsi kurikulum yang dipilih, catatannya adalah siswa tidak dibebani tuntutan menuntaskan seluruh capaian kurikulum untuk kenaikan kelas maupun kelulusan, dan pelaksanaan kurikulum berlaku sampai akhir tahun ajaran," tegas Mendikbud.

Modul belajar PAUD dijalankan dengan prinsip "Bermain adalah Belajar". Proses pembelajaran terjadi saat anak bermain serta melakukan kegiatan seharihari. Sementara itu, untuk jenjang pendidikan SD modul belajar mencakup rencana pembelajaran yang mudah dilakukan secara mandiri oleh pendamping baik orang tua maupun wali. "Modul tersebut diharapkan akan mempermudah guru untuk memfasilitasi dan memantau pembelajaran siswa di rumah dan membantu orang tua dalam mendapatkan tips dan strategi dalam mendampingi anak belajar dari rumah," ucap Mendikbud.

Untuk membantu siswa yang terdampak pandemi dan berpotensi tertinggal, Mendikbud mengimbau guru perlu melakukan asesmen diagnostik. Asesmen dilakukan di semua kelas secara berkala untuk mendiagnosis kondisi kognitif dan non-kognitif siswa sebagai dampak pembelajaran jarak jauh.

Asesmen non-kognitif ditujukan untuk mengukur aspek psikologis dan kondisi emosional siswa, seperti kesejahteraan psikologi dan sosial emosi siswa, kesenangan siswa selama belajar dari rumah, serta kondisi keluarga siswa. Asesmen kognitif ditujukan untuk menguji kemampuan dan capaian pembelajaran siswa. Hasil asesmen digunakan sebagai dasar pemilihan strategi pembelajaran dan pemberian remedial atau pelajaran tambahan untuk peserta didik yang paling tertinggal.
Pemerintah juga melakukan relaksasi peraturan untuk guru dalam mendukung kesuksesan pembelajaran di masa pandemi Covid-19. "Guru tidak lagi diharuskan untuk memenuhi beban kerja 24 jam tatap muka dalam satu minggu sehingga guru dapat fokus memberikan pelajaran interaktif kepada siswa tanpa perlu mengejar pemenuhan jam," jelas Mendikbud. Mendikbud berharap kerja sama semua pihak dapat terus dilakukan. Orang tua diharapkan dapat aktif berpartisipasi dalam kegiatan proses belajar mengajar di rumah, guru dapat terus meningkatkan kapasitas untuk melakukan pembelajaran interaktif, dan sekolah dapat memfasilitasi kegiatan belajar mengajar dengan metode yang paling tepat. "Kerja sama secara menyeluruh dari semua pihak sangat diperlukan untuk menyukseskan pembelajaran di masa pandemi Covid-19," pesan Mendikbud.

\section{METODE}

Prosedur

Seperti kita ketahui kepala sekolah saat ini sedang dihadapkan pada penerapan 3 kebijakan yang mendasar dari pemerintah untuk dilaksanakan di sekolah. Sepertinya praktik baik dalam menyikapi peraturan itu dibutuhkan integrasi kegiatan yang satu dan lainnya menjadi saling terkait dalam buah pikir kegiatan. Kegiatan Praba (Praktik Baik) yang akan menjadi tema bahasan ini merupakan perpaduan 3 komponen penting yang saat ini benar benar baru dan harus dipadukan dalam integrasi kegiatan yaitu: 1 . Kurikulum Dalam kondisi khusus 2. Penyelenggaraan Belajar Dari Rumah 3. Empat Pokok Kebijakan Pendidikan "Merdeka Belajar". Kegiatan praktik baik yang mengacu pada ketiga pedoman kebijakan itu menantang seorang kepala sekolah agar terus menjamin pembelajaran yang dilakukan oleh guru di satuan pendidikan tetap terjamin berkualitas.

Menyikapi kurikulum dalam kondisi khusus ini salah satu cara terbaik menghadapinya adalah dengan cara penyederhanaan kompetensi dasar untuk setiap mata pelajaran, sehingga berfokus pada kompetensi esensial dan kompetensi prasyarat untuk kelanjutan pembelajaran di tingkat selanjutnya. Dalam kurikulum darurat seperti yang tertuang dalam Kepmendikbud No. 719/P/2020 sekolah dapat menyederhanakan kurikulum secara mandiri. Apa yang dilakukan di SMK 11 Malang dalam menghadapi kondisi ini? Tentunya tidak dapat dilakukan seorang diri oleh kepala sekolah. Setiap matpel produktif, normatif dan adaptif masing masing memiliki karakter yang berbeda sesuai tuntutan kuriklum dan ditujukan untuk kemajuan belajar yang dibutuhkan, kurikulum darurat yang diterapkan di SMK Negeri 11 Malang dirancang supaya memudahkan proses pembelajaran di masa pandemi ini terutama bagi Guru supaya Memiliki acuan kurikulum yang sederhana, efektif dan efisien ketika mengajar secara virtual, guru fokus pada pola 
pembelajaran yang esensial dan kontekstual, dan kesejahteraan psikososial guru meningkat. Siswa supaya tidak dibebani tuntutan menuntaskan seluruh capaian kurikulum dan dapat berfokuspada pendidikan dan pembelajaran yang esensial dan kontekstual, kesejahteraan psikososial siswa meningkat. Orang tua supaya mempermudah pendampingan pembelajaran di rumah dan kesejahteraan psikososial orangtua meningkat.

\section{Instrumen}

Observasi untuk mensosialisasi cara supervisi yang berbeda di masa pandemi covid 19 yaitu memberikan informasi supaya guru menuliskan diskripsi diri saat melaksanakan pembelajaran daring, memberikan informasi bahwa implementasi pembelajaran daring terbaik akan diberikan penghargaan sekaligus sebagai model, Google drive merupakan tempat pengumpulan diskripsi pembelajaran daring dari masing masing guru, dan sesuai protokol kesehatan maka observasi dianggap sebagai kegiatan supervisi yang minim kontak dengan sesama guru dan memiliki kemudahan dalam penyusun laporan kegiatan.

Membuka format isian untuk guru. Mengirimkan link pengisian format gooogle form. Memberi pengumuman supaya guru mengisikan berbatass waktu. Pelaksanaan tanggal 7 September sd 30 September 2020. Guru mengisikan di format google drive berupa praktik baik pembelajaran yang dilakukan selama masa pandemi.

Instumen berupa assesmen bagaimana kegiatan guru mengajar, kisi-kisi kegiatan mengajar berupa platform pembelajaran yang digunakan, kegiatan apa saja yang sudah dilakukan guru dalam mengembangkan konten belajar yang dibagikan ke siswa. Bagaimana guru mengevaluasi materi kegiatan serta dokumen penting lainnya sehingga dapat digunakan seberapa jauh materi kegiatan itu dapat membawa dampak bagi peningkatan kompetensi atau kebermanfaatannya bagi siswa.

\section{Pemecahan Masalah}

\section{Penerapan kurikulum dalam kondisi khusus}

Penerapan kurikulum kondisi khusus ini perlu disupervisi karena proses pembelajaran sulit dijamin kualitasnya bila kegitatan penerapannya tidak diorganisasi dengan baik. Dengan jumlah guru yang lebih dari 90 orang. Maka kegiatan supervisi bagaimana guru menerapkannya dalam pembelajaran harus dikaji bagaimana kesulitan yang dihadapi.

Tahap Perencanaan Penerapan Kurikulum dalam kondisi khusus melaksanakan rapat kegiatan supervisi yang ditujukan untuk mengetahui sejauh mana penerapan kurikulum kondisi khusus, hasil dari rapat diperoleh komitmen bersama bahwa guru normatif adaptif wajib menerapkan salah satu model pembelajaran problem base, project base atau tematik learning pada saat proses pembelajaran.

Tahap Pelaksanaan Kurikulum dalam kondisi khusus melaksanakan kegiatan supervisi dengan mengamati RPP yang ada. Membawa instrumen supervisi memastikan guru punya rencana inovasi pembelajaran. Terutama menyikapi kurikulum dalam kondisi kusus dengan rancangan pembelajaran kontekstual learning, tematik, project base learning atau lainnya bagi guru normatif dan adaptif. Memastikan guru melaksanakan pembelajaran project teaching factory bagi guru produktif yang siap dengan pasangan industri dan jadwal bloknya. Mencatat semua aktifitas saat pelaksanaan pembelajaran berbagai kelebihan dan kekurangan dan segera mencatat peristiwa yang ingin digunakan untuk bahan evaluasi dan refleksi. Memberi catatan penting rencana inovasi untuk project base learning atau kontekstual learning yang akan ditampilkan di expo pembelajaran. Memberikan catatan bagi guru yang belum punya teching factory untuk menindaklanjuti bersama industri pasangan. Serta segera membuat jadwal pelaksanaan sinkronisasai kurikulum.

Tahap Evaluasi/Refleksi dan RTL pada kurikulum kondisi khusus. Pada tahapan ini catatan hasil supervisi dikomunikasikan, ditunjukkan beberapa hal yang perlu diperbaiki pada proses pembelajaran berikutnya. Memberi catatan rencana tindak lanjut. Sepakat dengan asesi pelaksanaan tidak lanjut, termasuk melapor hasil tindak lanjut. Menyarankan segera mencari industri pasangan bila pelajaran produktif belum menghasilkan Teaching factory, serta produk yang bisa dijual.

Tahapan Ekstra Kurikulum Kondisi Khusus mendokumentasikan semua catatan supervisi, foto kegiatan dan bila ada video saat kegiatan pembelajaran bisa diangkat sewaktu waktu sebagai contoh yang benar maupun yang belum sesuai sebagai bahan refleksi maupun promosi kegiatan pembelajaran di sekolah.

\section{Kegiatan Merdeka Belajar}

Begitu pentingnya kegiatan dan mengelola integrasi kombinasi PJJ, merdeka belajar dan kurikulum kondisi khusus hingga dipastikan pembelajaran ini menjadi bermakna dan dapat dilakukan oleh siswa dalam kondisi apapun. Begitu pula pentingnya upaya memastikan kegiatan pembelajaran integrasi ini berlangsung dengan baik, kepala sekolah harus melakukan kontrol melalui supervisi kegiatan. Berikut tahapan pelaksanaan Merdeka belajar.

Tahap perencanaan kegiatan Merdeka Belajar agar pelaksanaan dapat berlangsung dengan baik, mengajak berpikir arti merdeka belajar dalam diskusi, lalu mengajak komitmen bersama untuk diimplementasikan. Pada perencanaan kegiatan disepakati tidak semua kurikulum dituntaskan tapi 
mengerti kebutuhan siswa akan belajar. Selalu dipetakan apa saja sesuai dengan potensi siswa, guru baik dibidang akademis maupun non akademis.

Tahap Pelaksanaan Kegiatan Merdeka Belajar. Pembelajaran dalam suasana yang fun, menantang, memberi pengalaman langsung di kehidupan sehari hari, menyenangkan sehingga ada makna yang mendasar adanya suasana merdeka belajar. Sistem penugasan bisa diberi kebebasan oleh siswa dalam mengelola kontekstual learning sesuai dengan kondisi, situasi, minat dan kemampuan siswa dalam mempelajari problem base yang kita jadikan rangsangan mereka itu untuk belajar.

Tahap Evaluasi/Refleksi dan Tindak Lanjut Kegiatan Merdeka Belajar menyusun laporan dan membahas tentang keterlaksanaan pada proses pembelajaran ini. Ditinjau pada semua aspek yang dinilai saat siswa mengumpulkan tugas tugas projeck, kontekstual, tematik atau apapun yang dikerjakan siswa secara aktif memperoleh pengalaman belajar sesuai kemampuan, karakter diri dan sarana yang dimiliki serta tahapan prinsip yang harus dilalui sesuai situasi kondisi. Didokumentasikan sebagai dokumen evaluasi. Juga bisa digunakan menjadi tindak lanjut pada pembelajaran berikutnya. Sebagai bahan rencana tindak lanjut upaya upaya pembinaan berikutnya.

Tahapan Ekstra Kegiatan Merdeka Belajar mendokumentasikan kegiatan pembelajaran dengan konsep merdeka belajar. Keberhasilan project base dan portofolio siswa yang berhasil baik maupun yang belum dapat digunakan sebagai motivasi sekaligus promosi bagi kebutuhan untuk merancang pembelajaran selanjutnya.

\section{Pembelajaran Jarak Jauh}

Tetap dibutuhkan wawasan dan contoh nyata melalui guru yang sudah piawai atau leading dalam penggunaan IT untuk sarana interaksi belajar. Namun integrasi pembelajaran jarak jauh, merdeka belajar dan penerapan kurikulum kondisi khusus dibutuhkan komitmen bersama.

Tahapan Perencanaan Kegiatan Pembelajaran Jarak Jauh, apa saja model pembelajaran jarau jauh yang sudah pernah dilaksanakan. Seberapa efisien yang dilakukan guru dalam interaksi pembelajaran. Seberapa besar tingkat partisipasi siswa dalam mengukuti pemebalajaran jarak jauh. Seberapa berat tugas dan beban belajar itu dapat dilihat dari prosentasi siswa memenuhi tugas guru dan portofolio yang dikirim sesuai jadwal yang ditentukan. Harus ada diagram alur kegiatan yang menjadi landasan bersama.

Tahapan Pelaksanaan Pembelajaran Jarak Jauh sangat penting mengetahui detail masalah saat menjalankan proses pembelajaran hal ini terkait dengan mencari solusi bersama tujuannya adalah menjamin kepuasan siswa dalam proses belajar. Fleksibilitas dalam pelaksanaan itu menjadi bagian tak terpisahkan dengan motto siswa adalah pelanggan kita anak kita yang perlu dilayani. Apapun masalahnya harus dicatat untuk merubah keputusan dari rencana pembelajaran bila kenyataannya tidak mungkin bisa dilaksanakan oleh semua siswa. Selalu siapkan catatan untuk tahap pelaksanaan ini. Jangan lupa dokumentasi kegiatan dan apapun keterlaksanaan dan perubahan ditulis runtut jadi bagian dokumen pelaksanaan kegiatan.

Tahapan Evaluasi/Refleksi dan Rencana Tindak Lanjut PJJ, evaluasi menjadi modal untuk melakukan perbaikan kegiatan serupa. Dalam evaluasi bersama ini sering menjadi inspirasi dan menemukan solusi bersama ketika ada yang lain memiliki persamaan masalah dan mampu memberikan urun saran tentang inovasi yang sudah dijalani. Kegiatan evaluasi dan refleksi ini juga diharap memperhatikan rencana tindak lanjut serta rekomendasi hasil evaluasi supaya diikuti dan dilaksanakan.

Tahapan Ekstra Kegiatan Pembelajaran Jarak Jauh mendokumentasi berbagai aktifitas yang dilakukan bisa bentuk laporan, foto, MOU, dan membuat video keberhasilan sebagai bahan promosi kita telah berhasil melakukan kegiatan layanan pembelajaran jarak jauh dengan hasil yang baik maupun solusi dalam menghadapinya.

\section{HASIL DAN PEMBAHASAN}

Hasil Kegiatan Supervisi terlaksana efektif dengan protokol kesehatan yang tepat dalam memanfaatkan media IT. Hal ini ditunjukkan oleh empat keunggulan. Keunggulan petama adalah mampu menguasai multi platform pembelajaran daring berbasis media IT secara lengkap. Keunggulan kedua adalah mempunyai web blok pribadi yang diisi dengan konten materi pembelajaran. Keunggulan ketiga adalah mampu membuat media media pembelajaran yang sudah ditrekam dan divideokan. Keunggulan terakhir adalah mampu mengelola LMS ( Learrning Manajemen Sistem) Google class room dan membantu kesulitan guru dalam proses pembelajaran daring terlayani secara efektif dalam pelaksanaan pembelajaran.

Dari masing masing kelas unggulan 1,2,3 dan 4. Kesimpulannya guru terbantu dalam kesulitan pembelajaran daring. Kompetensi guru meningkat dalam proses pembelajaran daring. Kenyatannya guru ternyata tidak terlalu lama menghadapi permasalahan pembelajaran melalui daring untuk terbiasa dalam penguasaan media IT. Pembelajaran daring di masa pendemi covid daring terjamin berkualitas, lebih utama lagi adalah memberi makna bagi siswa.

Metoda Project Base Learning sesuai SK KD mudah diimplementasikan oleh siswa. Adanya fleksibiltitas waktu akses pembelajaran menjadi keunggulan juga karena siswa hanya dibatasi rentang waktu pengerjaan yang proporsional. Penerapan penyederhanaan kurikulum menjadikan siswa memiliki 
wawasan yang lebih luas bahwasannya pendidikan kejuruan yang dipelajari ternyata terkait kuat dengan mata pelajaran normatif dan adaptif. Teaching factory pada pembelajaran produktif dijadikan dikembangkan memikirkan minat siswa untuk mencari SK KD produktif yang dapat melayani masyarakat dan memasarkan keterampilannya untuk dikembangkan sebagai bekal life skill di saat mereka lulus punya bekal kewirausahaan.

\section{PENUTUP}

Pembelajaran daring yang efektif dan memberi makna pada siswa jika dilakukan pemilihan yang tepat SK KD yang di Project Base Learning kan. Normatif dan adaptif memberi tugas dengan memyederhanakan konten materi ajar dari kurikulum yang dipilihkan pada pembelajaran yang terhubung dengan tugas dan peran siswa sehari hari di rumah. Sedangkan untuk produktif difokuskan pada pembelajaran teaching factory yang menguatamakan peran siswa untuk menghasilkan produk dan jasa dan diprioritaskan melatih kewirausahaan.

\section{DAFTAR PUSTAKA}

Darmalaksana, W. (2020). WhatsApp Kuliah Mobile. Bandung: Fakultas Ushuluddin UIN Sunan Gunung Djati Bandung.

Firdaus. (2006). Reformasi Pembelajaran Menuju Kualitas Insan Bertaraf Dunia. Pekanbaru: Witra Irzani.

Gikas, J., \& Grant, M. M. (2013). Mobile computing devices in higher education: Student perspectives on learning with cellphones, smartphones \& social media. Internet and Higher Education. https://doi.org/10.1016/jjheduc.2013.06.002

He, W., Xu, G., \& Kruck, S. (2014). Online IS Education for the 21st Century . Journal of Information Systems Education.
Kuntarto, E. (2017). Keefektifan Model Pembelajaran Daring dalam Perkuliahan Bahasa Indonesiadi Perguruan Tinggi. Indonesian Language Education and Literature, 3 (1), 99110.10.24235/ileal.v3i1.1820

Majid, A. (2014). Strategi Pembelajaran. Bandung: Remaja Rosdakarya.

Mamat, S.B. dkk, (2007). Pedoman Pelaksanaan Pembelajaran Tematik. Jakarta: Dirjen Kelembagaan Agama Islam.

Pangondian, R. A., Santosa, P. I., \& Nugroho, E. (2019). Faktor-Faktor yang Mempengaruhi Kesuksesan Pembelajaran Daring Dalam Revolusi Industri 4.0. In Seminar Nasional Teknologi Komputer \& Sains (SAINTEKS) (Vol. 1, No. 1). https://www.kajianpustaka.com/2020/06/pembelaj aran-tematik.html

Rusman. (2011). Model-Model Pembelajaran Mengembangkan Profesionalisme Guru. Jakarta: Rajawali Pers.

Rusman. (2012). Model-Model Pembelajaran: Mengembangkan Profesionalisme Guru. Jakarta: Raja Grafindo Persada.

Suryosubroto. (2009). Proses Belajar Mengajar di Sekolah. Jakarta: Rhineka Cipta.

Zhang, D., Zhao, J. L., Zhou, L., \& Nunamaker, J. F. (2004). Can e-learning replace classroom learning? Communications of the ACM. https://doi.org/10.1145/986213.986216 